\title{
Aspek budaya melayu dalam pengajaran dan pembelajaran bahasa melayu sebagai bahasa asing
}

\author{
The Aspects of Malay Culture in Teaching and Learning of Malay as a Foreign Language \\ Noor Zuhidayah Muhd Zulkifli \\ zuhidayah@fbk.upsi.edu.my \\ Universiti Pendidikan Sultan Idris, Tanjung Malim, Perak, Malaysia \\ Wan Muna Ruzanna Wan Mohamad \\ munaruzanna@ukm.edu.my
}

\author{
Shahlan Surat \\ drshahlan@ukm.edu.my
}

Jamaludin Badusah

jhb@ukm.edu.my

Universiti Kebangsaan Malaysia, Bangi, Selangor, Malaysia

DOI: https://doi.org/10.37134/pendeta.vol10.9.2019

\begin{abstract}
ABSTRAK
Kajian ini memfokuskan aspek budaya Melayu yang diterapkan dalam pengajaran dan pembelajaran Bahasa Melayu sebagai bahasa asing berdasarkan hubungan antara bahasa dan budaya yang saling berkait rapat. Kajian ini dijalankan adalah untuk mengkaji komponen budaya Melayu yang diterapkan dalam pengajaran dan pembelajaran Bahasa Melayu sebagai bahasa asing. Kaedah kuantitatif yang menggunakan soal selidik dijalankan untuk mengumpul data. Seramai 30 orang pelajar program Bahasa Melayu di Tokyo University of Foreign Studies (TUFS), Jepun terlibat dalam kajian ini. Hasil kajian menunjukkan bahawa pelajar-pelajar bersetuju bahawa aspek budaya Melayu perlu dimasukkan dalam kurikulum Bahasa Melayu. Dapatan kajian juga menunjukkan aspek budaya Melayu yang diterapkan dalam kelas Bahasa Melayu berada pada tahap yang tinggi (min=3.58) yang melibatkan kerangka budaya 3P yang mengandungi tiga dimensi budaya, iaitu produk, praktik dan perspektif. Perspektif budaya Melayu merupakan dimensi budaya yang paling kerap diterapkan dalam PdP Bahasa Melayu dengan min=3.80, diikuti praktik budaya Melayu ( $\min =3.73$ ) dan produk budaya Melayu (min=3.20). Hasil kajian juga menunjukkan komponen budaya Melayu yang paling kerap diterapkan adalah agama Islam. Secara kesimpulannya, proses pengajaran dan pembelajaran Bahasa Melayu di TUFS melibatkan aspek budaya Melayu dan merangkumi pelbagai komponen budaya Melayu.
\end{abstract}

Kata kunci: budaya Melayu; kerangka budaya; bahasa Melayu sebagai bahasa asing

\section{ABSTRACT}

This study focuses on aspects of Malay culture applied in the teaching and learning of Malay as a foreign language based on the interrelationship between language and culture which are closely related. This study is conducted to investigate the components of Malay culture that are applied in the teaching and learning of Malay as a foreign language. Quantitative method through questionnaires was conducted to collect data. A total of 30 students of the Malay language program at Tokyo University of Foreign Studies (TUFS), Japan were involved in this study. The results show that students agreed on the involvement of Malay culture in the Malay language curriculum. The findings also indicate that the aspects of Malay culture were applied in the Malay language teaching and learning at a high level (mean=3.58) involving a cultural framework (3Ps) that contains three cultural dimensions: product, practice and perspective. The Malay cultural perspectives are often applied in the Malay language teaching and learning (mean=3.80), followed by the Malay cultural practices (mean=3.73) and the Malay cultural product (mean=3.20). The results of this study also showed the most 
common Malay cultural component integrated is Islam. In conclusion, the process of the Malay language teaching and learning at TUFS involved aspects of Malay cultural and included various Malay cultural components.

Keywords: Malay culture; cultural framework; Malay as a foreign language

\section{PENGENALAN}

Bahasa Melayu telah lama mendapat tempat di institusi pengajian tinggi di luar negara. Buktinya, bahasa Melayu ditawarkan di puluhan universiti di Eropah, Australia, New Zealand, Amerika Utara serta turut diajarkan di rantau Asia Tenggara, Asia Timur dan Asia Utara (Awang Sariyan, 2017). Sebagai contoh, di China sahaja, terdapat 13 buah universiti yang menawarkan kursus Bahasa Melayu sama ada sebagai kursus major atau minor (Zaiton \& Hawa Mahfuzah, 2019). Di Jepun pula, terdapat tiga buah universiti yang menawarkan kursus Bahasa Melayu sebagai kursus major, manakala, 20 buah universiti lain menawarkan Bahasa Melayu sebagai subjek elektif atau subjek bahasa kedua (Wan Mohd Saophy Amizul, 2006). Keadaan ini menunjukkan bahawa pengajian Bahasa Melayu kian berkembang di seluruh pelosok dunia.

Atas dasar perkembangan ini, perencanaan yang rapi untuk proses pengajaran dan pembelajaran (PdP) bahasa Melayu perlu dilakukan untuk memastikan pelajar dapat menguasai bahasa Melayu dengan baik. Menurut Zulkifley (2014), program Bahasa Melayu perlu dirancang secara menyeluruh dan merangkumi keseluruhan aspek pengetahuan bahasa Melayu seperti kosa kata, nahu, aspek budaya (merangkumi sistem nilai, pemikiran dan laia-lain) serta kekangan sosial semasa berbahasa Melayu. Maksudnya, program bahasa Melayu yang lengkap bukan hanya tertumpu pada pengajaran aspek linguistik, tetapi turut merangkumi aspek sosial atau lebih tepat lagi aspek budaya Melayu yang melatari aspek bahasa Melayu. Hal ini demikian kerana kandungan sebenar sesuatu bahasa bukanlah tatabahasa dan perbendaharaan kata bahasa tersebut, tetapi budaya yang diungkapkan melalui bahasa (National Standards in Foreign Language Education Project (NSFLEP, 1999). Nugent (2019) turut menegaskan bahawa PdP bahasa bukan sahaja tentang perbendaharaan kata dan struktur tatabahasa, namun, turut melibatkan pemahaman terhadap budaya. Pelajar perlu mengetahui budaya bahasa yang dipelajari kerana terdapat budaya membekalkan makna kepada bahasa yang digunakan.

Selain itu, Salim (2017) dan Tanrıverdi dan Apak (2008) menegaskan bahawa kejayaan pembelajaran bahasa sangat memerlukan pelajar untuk mengetahui budaya yang melatari bahasa yang dipelajari. Hal ini kerana bahasa dan budaya saling berkait rapat dan tidak boleh dipisahkan. Bahasa tidak boleh dipelajari tanpa melibatkan budaya masyarakat yang menuturkan bahasa tersebut (Muho \& Roseni 2016). Menurut Junaini Kasdan et al. (2018), pembelajaran bahasa perlu melalui pembelajaran budaya, begitu juga sebaliknya, pembelajaran budaya perlu melalui pembelajaran bahasa. Hal ini bermaksud kedua-dua aspek perlu disatukan dan tidak boleh diajar secara terpisah. Mumu (2017) juga menegaskan bahawa adalah mustahil untuk mempelajari bahasa tanpa menggunakan makna yang tepat yang bergantung pada penggunaan elemen budaya yang sesuai. Pembelajaran bahasa melalui budaya juga dapat mengembangkan dan meningkatkan tahap penguasaan linguistik pelajar (Kuo \& Lai, 2006).

Sehubungan dengan itu, PdP Bahasa Melayu sangat memerlukan aspek budaya sebagai elemen yang disatukan dengan pengajaran bahasa. Hal ini kerana masyarakat Melayu sangat terikat kuat dengan aspek budaya Melayu (Awang, Maros \& Ibrahim, 2012). Masyarakat Melayu sangat menitikberatkan penggunaan bahasa yang sesuai demi menjaga hubungan antara satu sama lain. Menurut Goddard dan Wierzbicka (1997), nilai budaya Melayu sangat mementingkan kehalusan semasa bertutur kerana bahasa mempunyai makna sampingan tentang kesopanan dan adab seseorang individu. Dahlia (2009) turut menyatakan bahawa nilai budaya masyarakat Melayu cenderung untuk memaparkan etika yang betul terutamanya apabila berinteraksi dengan orang lain. Keadaan ini menyebabkan pembelajaran bahasa Melayu bukan sahaja tentang bahasa Melayu tetapi perlu menyentuh aspek budaya Melayu untuk memastikan pelajar dapat menggunakan bahasa Melayu dengan betul dan sesuai sama ada ketika berinteraksi secara lisan mahupun tulisan. 
Oleh hal yang demikian, pengajaran dan pembelajaran bahasa Melayu sebagai bahasa asing perlu diajar bersama aspek budaya Melayu. Aspek budaya Melayu yang diajarkan bersama dapat membantu pelajar untuk lebih mendalami bahasa Melayu dan dapat membantu pelajar untuk menguasai bahasa Melayu sepenuhnya.

\title{
BUDAYA DALAM PENGAJARAN DAN PEMBELAJARAN BAHASA
}

Bahasa dan budaya saling berkait rapat dan tidak boleh dipisahkan. Brown (2007) menyatakan bahawa budaya merupakan sebahagian daripada bahasa, begitu juga bahasa merupakan sebahagian daripada budaya. Walaupun bahasa dan budaya muncul sebagai dua bidang yang berbeza, namun, kedua-duanya mempunyai hubungan yang rapat dan mempengaruhi antara satu sama lain (Kuo \& Lai, 2006). Menurut Liu (2013), hubungan ini dapat dilihat dengan jelas kerana bahasa merupakan pembawa budaya dan mencerminkan budaya sesebuah masyarakat serta dibentuk dan dipengaruhi oleh budaya.

Dalam konteks pengajaran dan pembelajaran bahasa, khususnya bahasa asing, bahasa perlu diajar bersama budaya. Menurut Li dan Umemoto (2010), bahasa dan budaya mempunyai hubungan yang sangat kuat dan tidak boleh dipisahkan. Kehilangan salah satu aspek akan menyebabkan kekurangan aspek satu lagi khususnya apabila melibatkan pembelajaran bahasa. Hal ini ditegaskan oleh (Stockwell, 2018) bahawa,

\begin{abstract}
"Language and culture are closely interconnected, and students cannot have a comprehensive grasp of a language without understanding its culture. Because it is language in its cultural context that creates meaning, creating and interpreting meaning is done within a cultural framework."
\end{abstract}

Maksudnya, bahasa dan budaya saling berhubungan dan pelajar tidak akan memiliki penguasaan bahasa yang komprehensif tanpa memahami budaya. Hal ini kerana bahasa dalam konteks budayanya mewujudkan makna dan pentafsiran makna hanya dapat dilakukan dalam kerangka budaya. Pelajar hanya dapat mentafsir bahasa dengan tepat jika pelajar memahami budaya bahasa tersebut. Qu (2010) turut menegaskan bahawa pemahaman bahasa melibatkan bukan sahaja pengetahuan tentang tatabahasa, fonologi dan leksis tetapi juga tentang budaya. Pelajar perlu memahami budaya bahasa yang dipelajari untuk lebih menguasai bahasa dengan lebih komprehensif.

Selain itu, Shirazi (2017) juga menegaskan bahawa aspek budaya memainkan peranan penting dan perlu dilibatkan dalam proses PdP bahasa. Hal ini kerana aspek budaya dapat membantu pelajar supaya lebih tertarik dan bermotivasi untuk mempelajari bahasa (Chi-Jung \& Chuan-Ta, 2012). Menurut Rajabi dan Ketabi (2012), implikasi positif tentang penerapan aspek budaya dalam pengajaran bahasa telah diketahui dan diperakui, antaranya dapat memupuk sikap positif pelajar terhadap pembelajaran bahasa, dapat meningkatkan pembelajaran bahasa serta dapat mempermudah proses menguasai bahasa tersebut. Hal ini menjelaskan bahawa aspek budaya yang diterapkan dalam pengajaran bahasa dapat membantu pelajar daripada pelbagai aspek. Pelajar bukan sahaja lebih bermotivasi untuk mempelajari bahasa dengan adanya aspek budaya, malahan, dapat memudahkan proses pembelajaran seterusnya dapat menguasai bahasa secara sepenuhnya.

Oleh hal yang demikian, pemahaman terhadap budaya tidak boleh diabaikan dalam pengajaran bahasa. Pengajaran budaya dalam pengajaran dan pembelajaran bahasa perlu dijadikan sebagai nadi untuk memastikan kejayaan penguasaan bahasa pelajar.

\section{PERNYATAAN MASALAH}

Penerapan atau penglibatan aspek budaya dalam PdP bahasa telah lama diperdebatkan oleh sarjanasarjana Barat. Para sarjana Barat memperakui bahawa bahasa dan budaya saling berkait rapat dan tidak boleh dipisahkan (Brown, 2007; Salim, 2017). Aspek budaya tidak boleh diabaikan khususnya dalam pengajaran bahasa asing kerana pelajar yang mempelajari bahasa ini tidak mempunyai akses kepada persekitaran bahasa dan penutur natif (Liddicoat \& Crozet, 1997). Mumu (2017) juga 
menegaskan bahawa adalah mustahil untuk mempelajari bahasa sepenuhnya tanpa melibatkan pengetahuan budaya kerana makna yang tepat yang sangat bergantung pada budaya yang melatari sesuatu bahasa. Hal ini meletakkan aspek budaya sebagai satu aspek penting dan perlu disatukan dalam pengajaran bahasa asing.

Walau bagaimanapun, penerapan aspek budaya dalam pengajaran bahasa bukanlah sesuatu yang mudah. Hal ini kerana aspek budaya merupakan sesuatu yang kompleks kerana mengandungi beberapa komponen sama ada yang implisit atau eksplisit (Darmo, 2015; Dahlan, 2015). Mahmoud (2015) menegaskan bahawa budaya adalah satu konsep yang luas yang merangkumi keseluruhan aspek kehidupan manusia seperti kepercayaan, corak tingkah laku, tabiat, agama dan lain-lain yang berkait dengan kehidupan manusia. Keadaan ini menimbulkan persoalan tentang komponen budaya yang perlu disatukan dalam pengajaran bahasa khususnya Bahasa Melayu. Berdasarkan kajian-kajian mengenai bahasa dan budaya Melayu, didapati kajian-kajian lebih tertumpu pada aktiviti budaya dan pembangunan kit video dan bahan interaktif berasaskan budaya seperti yang dilakukan oleh Junaini et al. (2018) dan Mardian, Azman dan Yusfarina (2017). Kajian yang menerangkan aspek dan komponen budaya yang diterapkan dalam PdP bahasa Melayu masih kurang dilakukan berbanding kajian-kajian Barat.

Kajian yang mengkaji aspek budaya Melayu dalam PdP Bahasa Melayu perlu dilakukan kerana budaya Melayu tidak boleh diajarkan secara sewenang-wenangnya. Hal ini demikian kerana budaya Melayu dibentuk berdasarkan falsafah pemikiran Islam. Menurut Idris Zakaria (2012), perbahasan dengan kebudayaan Melayu telah mengiktiraf bahawa Islam dan falsafahnya merupakan unsur penting yang membentuk budaya masyarakat Melayu. Islam merupakan unsur dominan yang menyerap dalam sendi-sendi kebudayaan Melayu dan Islam mempunyai falsafahnya yang tersendiri terhadap budaya Melayu. Hal ini melibatkan produk budaya Melayu, praktik (amalan) budaya Melayu dan perspektif budaya Melayu harus berpaksikan ajaran Islam dan falsafahnya. Budaya Melayu yang diajarkan dalam PdP Bahasa Melayu juga perlu menonjolkan falsafah yang mengiringi sesuatu produk, praktik dan perspektif.

Di samping itu, meskipun bahasa Melayu telah tersebar dan dipelajari di peringkat antarabangsa, namun, kajian-kajian yang meneliti bahasa Melayu sebagai bahasa asing khususnya di luar negara masih sedikit. Tumpuan juga harus diberikan pada pengajian bahasa Melayu di luar negara kerana proses pengajaran dan pembelajaran tidak berlaku dalam persekitaran yang sebenar. Menurut Roshidah (2017), mempelajari sesuatu bahasa di luar rumpun bahasa tersebut memberikan cabaran yang besar bukan sahaja kepada guru, malahan pelajar juga. Pelajar hanya mendapat pendedahan yang terhad dan tidak dapat mempraktikkan bahasa dengan penutur asli secara langsung. Keadaan ini menyukarkan proses PdP Bahasa Melayu kerana pelajar tidak mempunyai pendedahan secara langsung terhadap bahasa dan budaya masyarakat yang menuturkan bahasa tersebut.

Justeru, kajian ini dijalankan untuk mengkaji aspek budaya dalam pengajaran dan pembelajaran Bahasa Melayu yang dipelajari di luar konteks penggunaan bahasa Melayu, iaitu di luar negara. Kajian ini perlu dijalankan bagi mendapatkan gambaran jelas tentang aspek budaya Melayu yang diterapkan dalam PdP Bahasa Melayu.

\section{OBJEKTIF KAJIAN}

Kajian ini dijalankan untuk mengkaji aspek budaya Melayu yang diterapkan dalam proses pengajaran dan pembelajaran Bahasa Melayu di luar negara, iaitu di Universiti Bahasa Asing Tokyo (Tokyo University of Foreign Studies, TUFS), Jepun. Terdapat dua objektif kajian, iaitu:

i. $\quad$ Mengenal pasti persepsi pelajar terhadap penerapan budaya Melayu dalam PdP Bahasa Melayu

ii. Mengkaji komponen budaya Melayu yang diterapkan dalam PdP Bahasa Melayu berdasarkan kerangka budaya 3P (Produk, Praktik, Perspektif) 


\section{KAJIAN LEPAS}

Pada umumnya, kajian-kajian yang mengkaji aspek budaya dalam PdP bahasa asing lebih tertumpu pada bahasa Inggeris sebagai bahasa asing (English as foreign language, EFL). Kajian bahasa Melayu sebagai bahasa asing lebih tertumpu pada aspek tatabahasa, kekangan yang dihadapi oleh pelajar asing semasa mempelajari bahasa Melayu serta strategi pembelajaran bahasa Melayu. Kajian yang menerangkan aspek budaya Melayu yang diterapkan dalam PdP bahasa Melayu sebagai bahasa asing masih sedikit, antaranya, kajian yang dijalankan oleh Junaini et al. (2018), Mardian, Azman dan Yusfarina (2017) dan Mazlina dan Siti Ajar (2016).

Antara kajian yang boleh dibincangkan adalah kajian yang dilakukan oleh Muho dan Roseni (2016) yang memfokuskan bahasa dan budaya Inggeris. Kajian ini bertujuan mengkaji tanggapan pelajar terhadap pembelajaran budaya di dalam kelas bahasa Inggeris, mengkaji aktiviti yang diyakini pelajar sebagai aktiviti yang berguna untuk mempelajari budaya dan mengkaji topik budaya yang digemari oleh pelajar. Data kajian ini dikumpul melalui soal selidik. Terdapat dua kumpulan responden dalam kajian ini, iaitu guru dan pelajar Bahasa Inggeris di empat buah sekolah menengah di Durres, Albania. Hasil kajian menunjukkan 100\% guru dan pelajar menyatakan bahawa unsur budaya sangat penting dalam pengajaran dan pembelajaran bahasa Inggeris dan unsur budaya boleh diajar di dalam kelas Bahasa Inggeris. Kajian juga mendapati empat aktiviti yang diyakini oleh pelajar dan guru untuk mempelajari budaya, antaranya berbincang mengenai isu semasa, berbincang mengenai persamaan dan perbezaan budaya, mendengar lagu dan melakukan projek berkaitan budaya. Bagi topik budaya pula, para guru dan pelajar menyatakan tiga topik yang digemari adalah simbol kebangsaan, kehidupan remaja dan komunikasi bukan lisan.

Kajian yang dijalankan oleh Junaini et al. (2018) adalah berkenaan pembangunan kit video pembelajaran bahasa Melayu berasaskan budaya Melayu. Kajian ini dijalankan dengan membangunkan sebuah kit video yang mengandungi 11 tema budaya Melayu, antaranya kata sapaan, makanan, pengenalan tentang keluarga, perayaan, pekerjaan, cuti umum, permainan tradisional, angka, alamat, alam sekitar dan cuaca. Data kajian ini dikumpul melalui kaedah kualitatif dengan melibatkan pemerhatian dan penglibatan langsung penutur asing. Kit video ini diperkenalkan kepada pelajar asing yang mengikuti kursus Bahasa Melayu di Institut Alam dan Tamadun Melayu, Universiti Kebangsaan Malaysia dan di Foreign Language Centre, FCU Taiwan. Hasil kajian yang diperoleh menunjukkan pelajar asing yang mempelajari bahasa Melayu melalui kit video ini menunjukkan respons positif.

Seterusnya, kajian Mardian, Azman dan Yusfarina (2017) bertajuk "Menyulam Budaya Dalam Pengajaran Bahasa Melayu Untuk Penutur Asing". Kajian ini bertujuan untuk mengkaji sama ada kaedah interaktif budaya dapat dipraktikkan dalam PdP Bahasa Melayu, mengkaji sama ada kaedah ini dapat meningkatkan pemahaman pelajar dan mengkaji aspek budaya Melayu yang sesuai dikaitkan dengan pengajaran bahasa. Kajian ini dijalankan di Universiti Tenaga Nasional (UNITEN). Data kajian dipungut melalui temu bual bersama guru dan pelajar serta penganalisisan dokumen. Dapatan kajian menunjukkan terdapat beberapa aspek budaya yang dipraktikkan dalam pengajaran bahasa Melayu, antaranya aspek sapaan, pakaian tradisional, permainan dan alat muzik tradisional dan makanan. Hasil kajian ini membuktikan bahawa aktiviti interaktif budaya berjaya diaplikasikan sama ada di dalam kelas mahupun di luar kelas. Pemahaman pelajar terhadap bahasa Melayu juga didapati lebih meningkat.

Selanjutnya, Mazlina dan Siti Ajar (2016) melakukan kajian tentang "The interesting teaching and learning of Malay language to foreign speakers: Language through cultures". Kajian ini menggunakan kaedah kualitatif dengan menjalankan temu bual terhadap pelajar dari University of Applied Science (WTG), Jerman yang mengikuti program Bahasa Melayu di Unviersiti Sains Malaysia (USM). Beberapa aktiviti budaya dijalankan di luar kelas seperti menari, memasak, pergi ke pasar Taman Tun Saadon, melancong dan program inap desa. Hasil kajian menunjukkan melalui aktiviti-aktiviti ini pelajar didedahkan dengan pengetahuan dan dapat bergaul dengan masyarakat tempatan. Pelajar-pelajar dapat bertukar fikiran dan mempelajari bahasa Melayu yang digunakan oleh masyarakat tempatan. Kajian ini juga mencadangkan supaya para guru dan penggubal kurikulum dapat merancang aktiviti yang dapat menarik minat pelajar agar PdP Bahasa Melayu dapat dilakukan dalam keadaan yang selesa untuk pelajar.

Berdasarkan kajian-kajian yang telah dijalankan ini, fokus kajian tempatan adalah tentang aktiviti 
budaya yang dijalankan sama ada di dalam kelas mahupun di luar kelas serta penggunaan dan pembangunan kit video dan bahan interaktif berasaskan budaya. Kajian lanjut mengenai aspek budaya yang diterapkan dalam PdP Bahasa Melayu di luar negara masih tidak disentuh. Isu ini perlu diketengahkan untuk mendapatkan gambaran sebenar aspek budaya Melayu yang diterapkan dalam PdP Bahasa Melayu di luar negara yang kurang mendapat pendedahan secara langsung terhadap aspek bahasa dan budaya Melayu.

\section{KERANGKA BUDAYA 3P}

Kajian ini menggunakan kerangka budaya 3P yang dikemukakan oleh National Standards in Foreign Language Education Project (NSFLEP, 1999) sebagai kerangka kajian. Menurut NSLFLEP (1999), budaya merangkumi tiga dimensi yang saling berkaitan yang dikenali sebagai kerangka 3P, iaitu produk, praktik (amalan) dan perspektif. Rajah 1 menunjukkan kaitan antara tiga dimensi utama budaya, iaitu perspektif budaya, praktik budaya dan produk budaya. Produk budaya merujuk kepada sebarang bentuk artifak sama ada yang boleh disentuh atau tidak boleh disentuh yang diciptakan, diadaptasikan dan digunakan oleh masyarakat, manakala, praktik budaya atau amalan budaya merujuk kepada corak tingkah laku dan interaksi sosial yang diterima dalam sesebuah masyarakat. Perspektif budaya pula merupakan pandangan terhadap dunia yang mendasari makna, sikap, nilai, kepercayaan, idea yang menjelaskan praktik budaya yang dilakukan oleh masyarakat dan produk budaya dihasilkan (NSLFLEP, 1999).

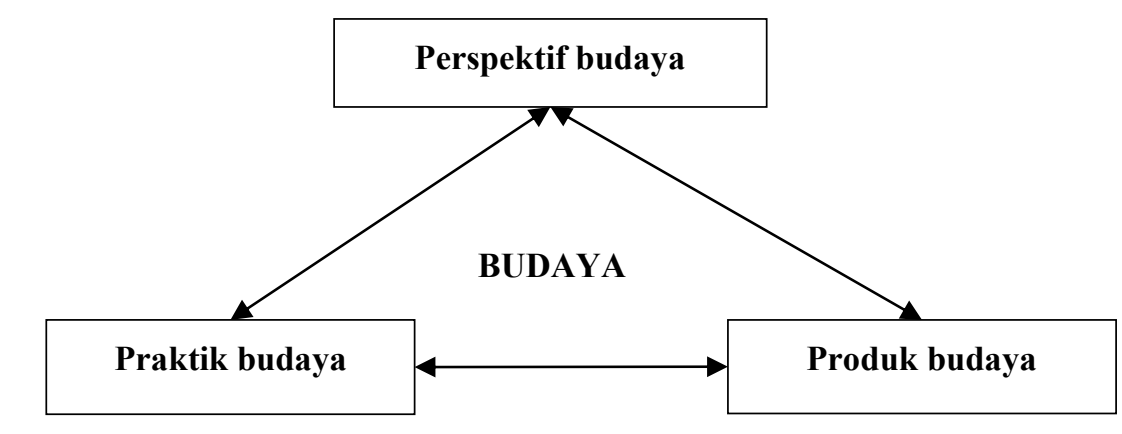

Rajah 1 Kerangka budaya 3P

(Diubah suai daripada National Standards in Foreign Language Education Project (1999: 47)

\section{METODOLOGI}

Kajian ini menggunakan reka bentuk kuantitatif (kaedah tinjauan) mengutip data kajian. Satu instrumen sahaja yang digunakan dalam kajian, iaitu instrumen soal selidik.

\section{Instrumen Kajian}

Instrumen soal selidik ini diadaptasi dan diubah suai berdasarkan instrumen yang dibina oleh Razi (2012), iaitu Inventory of Cultural Components (ICC). Instrumen asal ICC mengandungi 45 item yang mewakili sembilan komponen budaya. Namun, dalam kajian ini hanya 17 item sahaja dibincangkan berdasarkan kerangka budaya 3P seperti yang dikemukakan oleh National Standards in Foreign Language Education Project (1999). Item-item dalam instrumen ICC dipilih berdasarkan komponen budaya yang dapat mewakili budaya Melayu dalam PdP Bahasa Melayu. Soal selidik juga turut merangkumi soalan tentang pandangan pelajar terhadap penglibatan budaya Melayu dalam PdP Bahasa Melayu dengan pilihan jawapan. Secara keseluruhannya, soal selidik yang digunakan dalam kajian ini mengandungi dua bahagian, iaitu Bahagian A mengenai maklumat responden dan Bahagian B merangkumi 17 item mengenai komponen budaya Melayu yang melibatkan produk budaya, praktik budaya dan perspektif budaya. Responden dikehendaki menjawab Bahagian B berdasarkan skala 
Likert 5 mata, iaitu 1 - tidak pernah, 2 - jarang-jarang, 3 - kadang-kadang, 4 - selalu dan 5 - sangat kerap.

\section{Responden Kajian}

Responden kajian terdiri daripada 30 orang pelajar, iaitu 13 orang pelajar lelaki dan 17 orang pelajar perempuan yang mengikuti program Bahasa Melayu sebagai program major di Universiti Bahasa Asing Tokyo (Tokyo University of Foreign Studies, TUFS), Jepun. Pelajar-pelajar ini merupakan pelajar Ijazah Sarjana Muda tahun kedua, ketiga, keempat dan kelima. Pelajar tahun satu tidak dipilih dalam kajian ini kerana pelajar masih baharu dan kurang mempunyai pengalaman terhadap proses PdP Bahasa Melayu. Semua responden yang terlibat dalam kajian ini merupakan pelajar yang berasal dari Jepun.

\section{Pengumpulan dan Penganalisisan Data}

Pengumpulan data kajian dilakukan dengan mengedarkan soal selidik kepada pelajar semasa kelas Bahasa Melayu. Arahan diberikan terlebih dahulu sebelum pelajar menjawab soal selidik. Pelajar diberikan tempoh selama 40 minit untuk menjawab soal selidik. Setelah pelajar selesai menjawab, soal selidik dikumpulkan dan disemak untuk memastikan semua bahagian dijawab oleh pelajar. Kemudian, soal selidik yang dikumpulkan dianalisis menggunakan SPSS versi 25. Kajian ini menggunakan analisis deskriptif yang melibatkan kekerapan, peratusan, min dan sisihan piawai bagi membincangkan data yang diperoleh melalui soal selidik. Data-data dianalisis berdasarkan kerangka budaya 3P seperti yang telah dinyatakan.

\section{DAPATAN KAJIAN}

Bahagian ini membincangkan data-data yang diperoleh melalui soal selidik yang telah diedarkan kepada pelajar TUFS, Jepun. Data-data dalam bahagian ini dibincangkan dalam bentuk kekerapan, peratusan, min dan sisihan piawai. Skor min yang diperoleh pula diinterpretasikan berdasarkan interpretasi yang dikemukakan oleh Khumsikiew, Donsamak dan Saeteaw (2015) seperti Jadual 1.

Jadual 1: Interpretasi skor min

\begin{tabular}{cc}
\hline Skor min & Interpretasi \\
\hline $1.00-1.80$ & Paling rendah \\
$1.81-2.60$ & Rendah \\
$2.61-3.40$ & Sederhana \\
$3.41-4.20$ & Tinggi \\
$4.21-5.00$ & Paling tinggi \\
\hline
\end{tabular}

Bagi menjawab tujuan kajian satu, iaitu mengenai persepsi pelajar terhadap penerapan budaya Melayu dalam PdP Bahasa Melayu, soalan yang diberikan adalah seperti Jadual 2. Berdasarkan Jadual 2, didapati majoriti pelajar (100\%) bersetuju bahawa PdP bahasa Melayu perlu melibatkan aspek budaya Melayu. Dapatan juga menunjukkan bahawa aspek budaya Melayu perlu dilibatkan bersama PdP Bahasa Melayu dan tidak perlu diajar secara berasingan. Hal ini membuktikan bahawa aspek budaya Melayu sangat penting dalam PdP Bahasa Melayu dan perlu disatukan dengan pengajaran bahasa. 
Jadual 2 Persepsi pelajar terhadap penerapan budaya Melayu dalam PdP Bahasa Melayu

Adakah anda merasakan kurikulum pengajaran dan pembelajaran bahasa Melayu perlu melibatkan aspek budaya Melayu?

\begin{tabular}{ll|c|c}
\hline \multicolumn{1}{c|}{ Pilihan jawapan } & Kekerapan & Peratusan (\%) \\
\hline (i) & Ya & 30 & 100.0 \\
\hline (ii) & Tidak & 0 & 0 \\
\hline (iii) & Perlu diajar secara berasingan & 0 & 0 \\
\hline
\end{tabular}

Seterusnya, Jadual 3 menunjukkan skor min yang diperoleh bagi setiap dimensi yang terdapat dalam kerangka budaya $3 \mathrm{P}$.

Jadual 3 Skor min dan interpretasi dimensi budaya 3P

\begin{tabular}{lcc}
\hline \multicolumn{1}{c}{$\begin{array}{c}\text { Dimensi Budaya } \\
\text { Melayu }\end{array}$} & Skor min & Interpretasi \\
\hline Produk & & Sederhana \\
Praktik & 3.20 & Tinggi \\
Perspektif & 3.73 & Tinggi \\
\hline Min keseluruhan & 3.80 & Tinggi \\
\hline
\end{tabular}

Secara keseluruhannya, didapati penerapan aspek budaya Melayu dalam PdP bahasa Melayu di TUFS, Jepun melibatkan ketiga-tiga dimensi budaya, iaitu produk, praktik dan perspektif. Skor min keseluruhannya yang diperoleh adalah min=3.58 yang menunjukkan penerapan aspek budaya Melayu dalam PdP bahasa Melayu berada pada tahap yang tinggi. Perspektif budaya Melayu merupakan dimensi yang paling kerap diterapkan dalam PdP bahasa Melayu dengan skor min=3.80, diikuti praktik budaya Melayu (min=3.73) dan produk budaya Melayu (min=3.20). Hal ini menunjukkan bahawa penerapan budaya Melayu dalam PdP bahasa Melayu berada pada tahap yang tinggi.

Jadual 4 Analisis komponen-komponen produk budaya Melayu

\begin{tabular}{|c|c|c|c|c|c|c|c|c|}
\hline \multirow[t]{2}{*}{ Bil. } & \multirow[t]{2}{*}{ Komponen } & \multicolumn{5}{|c|}{$\begin{array}{c}\text { Kekerapan dan } \\
\text { peratusan }(\%)\end{array}$} & \multirow[t]{2}{*}{ Min } & \multirow[t]{2}{*}{$\begin{array}{l}\text { Sisihan } \\
\text { piawai }\end{array}$} \\
\hline & & $\mathbf{T P}$ & JJ & KK & $\mathbf{S}$ & SK & & \\
\hline 1. & Agama Islam & $\begin{array}{c}1 \\
(3.3)\end{array}$ & $\begin{array}{c}0 \\
(0.0)\end{array}$ & $\begin{array}{c}4 \\
(13.3)\end{array}$ & $\begin{array}{c}9 \\
(30.0)\end{array}$ & $\begin{array}{c}16 \\
(53.3)\end{array}$ & 4.30 & 0.95 \\
\hline 2. & Muzik Melayu & $\begin{array}{c}1 \\
(3.3)\end{array}$ & $\begin{array}{c}7 \\
(23.3)\end{array}$ & $\begin{array}{c}13 \\
(43.3)\end{array}$ & $\begin{array}{c}6 \\
(20.0)\end{array}$ & $\begin{array}{c}3 \\
(10.0)\end{array}$ & 3.10 & 1.00 \\
\hline 3. & Kesusasteraan Melayu & $\begin{array}{c}2 \\
(6.7)\end{array}$ & $\begin{array}{c}3 \\
(10.0)\end{array}$ & $\begin{array}{c}15 \\
(50.0)\end{array}$ & $\begin{array}{c}7 \\
(23.3)\end{array}$ & $\begin{array}{c}3 \\
(10.0)\end{array}$ & 3.20 & 0.99 \\
\hline 4. & Filem Melayu & $\begin{array}{c}1 \\
(3.3)\end{array}$ & $\begin{array}{c}5 \\
(16.7)\end{array}$ & $\begin{array}{c}14 \\
(46.7)\end{array}$ & $\begin{array}{c}8 \\
(26.7)\end{array}$ & $\begin{array}{c}2 \\
(6.7)\end{array}$ & 3.17 & 0.91 \\
\hline 5. & Kesenian Melayu & $\begin{array}{c}3 \\
(10.0)\end{array}$ & $\begin{array}{c}7 \\
(23.3)\end{array}$ & $\begin{array}{c}14 \\
(46.7)\end{array}$ & $\begin{array}{c}4 \\
(13.3)\end{array}$ & $\begin{array}{c}2 \\
(6.7)\end{array}$ & 2.83 & 1.02 \\
\hline 6. & Rancangan televisyen bahasa Melayu & $\begin{array}{c}3 \\
(10.0) \\
\end{array}$ & $\begin{array}{c}12 \\
(40.0) \\
\end{array}$ & $\begin{array}{c}11 \\
(36.7) \\
\end{array}$ & $\begin{array}{c}3 \\
(10.0) \\
\end{array}$ & $\begin{array}{c}1 \\
(3.3)\end{array}$ & 2.57 & 0.94 \\
\hline & & & & & Iin kese & uruhan & 3.20 & \\
\hline
\end{tabular}

Selanjutnya, Jadual 4 membincangkan komponen-komponen yang terdapat dalam dimensi produk budaya Melayu. Berdasarkan analisis yang dilakukan, didapati agama Islam merupakan komponen budaya Melayu yang mendapat skor min yang paling tinggi, iaitu min=4.30. Hal ini menunjukkan bahawa agama Islam merupakan komponen budaya Melayu yang paling kerap dimasukkan dalam PdP bahasa Melayu. Komponen yang mendapat skor min sederhana adalah kesusasteraan Melayu 
$(\min =3.20)$, filem Melayu ( $\min =3.17)$, muzik Melayu $(\min =3.10)$, kesenian Melayu $(\min =2.83)$, manakala, komponen yang mendapat skor min yang rendah adalah rancangan televisyen bahasa Melayu (min=2.57). Dapatan ini menunjukkan bahawa komponen-komponen ini jarang diterapkan dalam PdP bahasa Melayu.

Jadual 5 Analisis komponen-komponen praktik budaya Melayu

\begin{tabular}{|c|c|c|c|c|c|c|c|c|}
\hline \multirow[t]{2}{*}{ Bil. } & \multirow[t]{2}{*}{ Komponen } & \multicolumn{5}{|c|}{$\begin{array}{c}\text { Kekerapan dan } \\
\text { peratusan }(\%)\end{array}$} & \multirow[t]{2}{*}{ Min } & \multirow[t]{2}{*}{$\begin{array}{l}\text { Sisihan } \\
\text { piawai }\end{array}$} \\
\hline & & TP & JJ & KK & $\mathbf{S}$ & SK & & \\
\hline 1. & $\begin{array}{l}\text { Corak tingkah laku lisan masyarakat } \\
\text { Melayu }\end{array}$ & $\begin{array}{c}0 \\
(0.0)\end{array}$ & $\begin{array}{c}3 \\
(10.0)\end{array}$ & $\begin{array}{c}6 \\
(20.0)\end{array}$ & $\begin{array}{c}12 \\
(40.0)\end{array}$ & $\begin{array}{c}9 \\
(30.0)\end{array}$ & 3.90 & 0.96 \\
\hline 2. & $\begin{array}{l}\text { Corak tingkah laku bukan lisan } \\
\text { masyarakat Melayu }\end{array}$ & $\begin{array}{c}1 \\
(3.3)\end{array}$ & $\begin{array}{c}5 \\
(16.7)\end{array}$ & $\begin{array}{c}5 \\
(16.7)\end{array}$ & $\begin{array}{c}8 \\
(26.7)\end{array}$ & $\begin{array}{c}11 \\
(36.7)\end{array}$ & 3.77 & 1.22 \\
\hline 3. & $\begin{array}{l}\text { Hubungan antara anggota masyarakat } \\
\text { Melayu }\end{array}$ & $\begin{array}{c}0 \\
(0.0)\end{array}$ & $\begin{array}{c}3 \\
(10.0)\end{array}$ & $\begin{array}{c}8 \\
(26.7)\end{array}$ & $\begin{array}{c}10 \\
(33.3)\end{array}$ & $\begin{array}{c}9 \\
(30.0)\end{array}$ & 3.83 & 0.986 \\
\hline 4. & Gaya hidup masyarakat Melayu & $\begin{array}{c}0 \\
(0.0)\end{array}$ & $\begin{array}{c}3 \\
(10.0)\end{array}$ & $\begin{array}{c}5 \\
(16.7)\end{array}$ & $\begin{array}{c}13 \\
(43.3)\end{array}$ & $\begin{array}{c}9 \\
(30.0)\end{array}$ & 3.93 & 0.94 \\
\hline 5. & Hobi masyarakat Melayu & $\begin{array}{c}2 \\
(6.7)\end{array}$ & $\begin{array}{c}4 \\
(13.3)\end{array}$ & $\begin{array}{c}11 \\
(36.7)\end{array}$ & $\begin{array}{c}10 \\
(33.3)\end{array}$ & $\begin{array}{c}3 \\
(10.0)\end{array}$ & 3.27 & 1.05 \\
\hline 6. & $\begin{array}{l}\text { Kehidupan berkeluarga masyarakat } \\
\text { Melayu }\end{array}$ & $\begin{array}{c}1 \\
(3.3)\end{array}$ & $\begin{array}{c}1 \\
(3.3)\end{array}$ & $\begin{array}{c}12 \\
(40.0)\end{array}$ & $\begin{array}{c}9 \\
(30.0)\end{array}$ & $\begin{array}{c}7 \\
(23.3)\end{array}$ & 3.67 & 0.99 \\
\hline & & & & & Min kesel & uruhan & 3.73 & \\
\hline
\end{tabular}

Jadual 5 pula menunjukkan komponen-komponen praktik budaya Melayu. Secara keseluruhannya, komponen-komponen yang terdapat dalam praktik budaya Melayu mendapat skor min yang tinggi. Komponen praktik budaya Melayu yang mendapat skor min paling tinggi adalah gaya hidup masyarakat Melayu ( $\min =3.93)$, diikuti corak tingkah laku lisan masyarakat Melayu $(\min =3.90)$, hubungan antara anggota masyarakat Melayu ( $\min =3.83)$, corak tingkah laku bukan lisan masyarakat Melayu (min=3.77) dan kehidupan berkeluarga masyarakat Melayu (min=3.67). Dapatan ini menunjukkan bahawa komponen-komponen ini sering diterapkan dalam PdP bahasa Melayu. Hanya satu komponen praktik budaya yang mendapat skor min sederhana adalah hobi masyarakat Melayu (min=3.27). Hal ini menunjukkan bahawa hobi komponen ini kurang diterapkan dalam PdP bahasa Melayu.

Seterusnya, Jadual 6 menunjukkan komponen-komponen bagi perspektif budaya Melayu. Analisis menunjukkan pemikiran masyarakat Melayu mendapat skor min yang paling tinggi, iaitu $\min =4.23$. Hal ini menunjukkan bahawa komponen ini sering diterapkan dalam PdP bahasa Melayu. Komponen lain yang turut mendapat skor min yang tinggi, adalah sistem nilai masyarakat Melayu $(\min =4.10)$, kepercayaan masyarakat Melayu $(\min =4.07)$ dan norma masyarakat Melayu $(\min =3.57)$. Falsafah masyarakat Melayu mendapat skor min sederhana, iaitu min=3.03. Dapatan ini menunjukkan bahawa komponen ini kurang diterapkan dalam PdP bahasa Melayu. Walau bagaimanapun, secara keseluruhannya, perspektif budaya Melayu memperoleh skor min yang tinggi bagi keseluruhan item. Hal ini menunjukkan bahawa dimensi ini sering diterapkan dalam PdP bahasa Melayu di TUFS, Jepun. 
Jadual 6 Analisis komponen-komponen perspektif budaya Melayu

\begin{tabular}{|c|c|c|c|c|c|c|c|c|}
\hline \multirow[t]{2}{*}{ Bil. } & \multirow[t]{2}{*}{ Komponen } & \multicolumn{5}{|c|}{$\begin{array}{c}\text { Kekerapan dan } \\
\text { peratusan }(\%)\end{array}$} & \multirow[t]{2}{*}{ Min } & \multirow[t]{2}{*}{$\begin{array}{l}\text { Sisihan } \\
\text { piawai }\end{array}$} \\
\hline & & TP & JJ & KK & $\mathbf{S}$ & SK & & \\
\hline 1. & Pemikiran masyarakat Melayu & $\begin{array}{c}0 \\
(0.0)\end{array}$ & $\begin{array}{c}1 \\
(3.3)\end{array}$ & $\begin{array}{c}3 \\
(10.0)\end{array}$ & $\begin{array}{c}14 \\
(46.7)\end{array}$ & $\begin{array}{c}12 \\
(40.0)\end{array}$ & 4.23 & 0.77 \\
\hline 2. & Sistem nilai masyarakat Melayu & $\begin{array}{c}0 \\
(0.0)\end{array}$ & $\begin{array}{c}2 \\
(6.7)\end{array}$ & $\begin{array}{c}5 \\
(16.7)\end{array}$ & $\begin{array}{c}11 \\
(36.7)\end{array}$ & $\begin{array}{c}12 \\
(40.0)\end{array}$ & 4.10 & 0.92 \\
\hline 3. & Kepercayaan masyarakat Melayu & $\begin{array}{c}0 \\
(0.0)\end{array}$ & $\begin{array}{c}0 \\
(0.0)\end{array}$ & $\begin{array}{c}7 \\
(23.3)\end{array}$ & $\begin{array}{c}14 \\
(46.7)\end{array}$ & $\begin{array}{c}9 \\
(30.0)\end{array}$ & 4.07 & 0.74 \\
\hline 4. & Norma masyarakat Melayu & $\begin{array}{c}0 \\
(0.0)\end{array}$ & $\begin{array}{c}4 \\
(13.3)\end{array}$ & $\begin{array}{c}12 \\
(40.0)\end{array}$ & $\begin{array}{c}7 \\
(23.3)\end{array}$ & $\begin{array}{c}7 \\
(23.3)\end{array}$ & 3.57 & 1.01 \\
\hline 5. & Falsafah masyarakat Melayu & $\begin{array}{c}2 \\
(6.7) \\
\end{array}$ & $\begin{array}{c}9 \\
(30.0) \\
\end{array}$ & $\begin{array}{c}10 \\
(33.3) \\
\end{array}$ & $\begin{array}{c}4 \\
(13.3) \\
\end{array}$ & $\begin{array}{c}5 \\
(16.7) \\
\end{array}$ & 3.03 & 1.19 \\
\hline
\end{tabular}

\section{PERBINCANGAN}

Berdasarkan analisis yang telah dilakukan, didapati para pelajar bersetuju bahawa kurikulum Bahasa Melayu perlu melibatkan aspek budaya Melayu. Dapatan kajian ini jelas menunjukkan bahawa pelajar mempercayai bahawa aspek budaya Melayu sebagai satu elemen penting yang perlu disatukan dengan pengajaran bahasa Melayu dan tidak boleh dipisahkan atau diabaikan. Hasil kajian ini selari dengan dapatan Rostami (2016) dan Gorjian dan Aghvami (2017) yang mendapati bukan sahaja pelajar menyatakan aspek budaya perlu disatukan dalam kursus bahasa, malahan, para guru juga turut mempunyai pandangan yang sama. Kajian-kajian ini menunjukkan pandangan pelajar dan guru tentang aspek budaya dalam pengajaran bahasa adalah sesuatu yang tidak boleh dipisahkan. Hal ini menjelaskan lagi hubungan antara bahasa dan budaya yang sememangnya tidak boleh dipisahkan dan perlu disatukan dalam PdP bahasa khususnya.

Selain itu, analisis terhadap dimensi budaya Melayu yang diterapkan dalam PdP bahasa Melayu pula mendapati perspektif budaya Melayu merupakan dimensi yang paling kerap diterapkan bersama pengajaran bahasa Melayu. Dapatan ini menunjukkan bahawa komponen-komponen seperti pemikiran masyarakat Melayu, sistem nilai masyarakat Melayu dan kepercayaan masyarakat Melayu sangat dititikberatkan dalam pengajaran bahasa Melayu. Hal ini kerana setiap bahasa yang dituturkan mempunyai makna di sebaliknya yang sangat berkait rapat dengan pandangan masyarakat terhadap sesuatu perkara. Pandangan ini yang akhirnya membentuk tingkah laku manusia dan menghasilkan produk yang boleh diguna pakai dalam kehidupan seharian. Hal ini menjelaskan bahawa setiap produk dan praktik (amalan yang dilakukan) diperoleh daripada perspektif yang membentuk pandangan dunia bagi sesebuah komuniti budaya seperti yang dinyatakan oleh NSFLEP (1999). Dapatan kajian ini selari dengan kajian yang dilakukan oleh Byrd et al. (2011) yang mendapati perspektif budaya lebih ditekankan dalam proses PdP bahasa. Kajian tersebut juga mendapati masa yang diperuntukkan untuk dimensi perspektif adalah melebihi masa yang diperuntukkan untuk dimensi produk dan praktik.

Walaupun dapatan menunjukkan dimensi perspektif sebagai dimensi yang paling kerap diterapkan dalam PdP bahasa Melayu, namun, komponen yang mendapat skor min yang paling tinggi adalah agama Islam ( $\min =4.30$ ) yang merupakan salah satu produk budaya. Hal ini kerana agama dan budaya saling berkait rapat. Perbincangan tentang budaya harus melibatkan agama yang menjadi akar umbi sesuatu budaya khususnya bagi budaya Melayu yang sangat terikat kuat dengan agama Islam. Hal ini telah dijelaskan oleh Idris Zakaria (2012) bahawa Islam merupakan unsur dominan yang membentuk budaya Melayu. Segala produk, praktik dan perspektif yang dihasilkan dalam masyarakat Islam harus berlandaskan syariat yang telah digariskan dalam agama Islam. Menurut Zaitul Azma dan Ahmad Fuad (2011), agama Islam merupakan paksi serta landasan kepada pemikiran dan kebudayaan masyarakat Melayu. Berdasarkan kajian-kajian tempatan sebelum ini, 
komponen agama Islam dalam PdP bahasa Melayu kurang dibincangkan berbanding komponen budaya Melayu yang lain. Seharusnya komponen ini menjadi komponen utama yang diterapkan dalam PdP bahasa kerana komponen ini mempunyai pengaruh bukan sahaja terhadap bahasa Melayu, malahan terhadap komponen budaya Melayu yang lain.

Kajian juga menunjukkan skor min yang diperoleh bagi item falsafah masyarakat Melayu mendapat nilai min yang sederhana, iaitu $\min =3.03$ berbanding item lain dalam perspektif budaya Melayu. Hal ini menunjukkan bahawa komponen ini kurang diterapkan dalam PdP bahasa Melayu di TUFS. Menurut Idris Zakari (2012), Islam mempunyai falsafahnya tersendiri tentang kesenian dan kebudayaan Melayu. Oleh hal yang demikian, falsafah masyarakat Melayu sangat penting dan perlu kerap diintegrasikan dalam PdP Bahasa Melayu. Falsafah masyarakat Melayu dapat menjelaskan tentang penghasilan produk budaya Melayu dan amalan-amalan budaya yang dilakukan oleh masyarakat Melayu dalam kehidupan seharian. Apabila pelajar mengetahui dan memahami falsafah masyarakat Melayu, maka pelajar mempunyai kefahaman tentang cara hidup masyarakat Melayu, cara pemikiran masyarakat dan penggunaan serta penghasilan produk masyarakat Melayu. Keadaan ini akan membawa pelajar ke arah penggunaan bahasa Melayu yang tepat apabila melakukan interaksi dengan masyarakat Melayu. Pelajar juga dapat mentafsir butir bicara masyarakat Melayu dengan lebih baik.

Selain itu, terdapat beberapa komponen budaya yang mendapat skor min yang rendah berbanding komponen budaya yang lain terutamanya bagi produk budaya Melayu. Antara komponen yang mendapat skor min terendah adalah rancangan televisyen bahasa Melayu $(m i n=2.57)$. Dapatan ini menunjukkan bahawa komponen ini jarang diterapkan dalam PdP bahasa Melayu di TUFS, Jepun. Kajian-kajian tempatan yang melibatkan budaya dalam PdP bahasa Melayu juga tidak memperlihatkan komponen ini sebagai satu sumber pembelajaran budaya Melayu yang dapat membantu pembelajaran bahasa Melayu dalam kalangan pelajar. Hal ini menunjukkan bahawa rancangan televisyen kurang diberi perhatian sebagai komponen budaya yang boleh digunakan dalam PdP bahasa Melayu. Keadaan ini berbeza dengan PdP bahasa Inggeris yang melihat rancangan televisyen sebagai satu sumber pembelajaran bahasa dan budaya yang penting. Rancangan televisyen dapat memberikan input bahasa yang asli dan dapat menyumbang kepada pembelajaran bahasa serta dapat mencerminkan budaya bahasa tersebut (Webb 2018; Kramsch 1991).

Secara keseluruhannya, aspek budaya Melayu diterapkan dalam PdP bahasa Melayu di TUFS, Jepun pada tahap yang baik berdasarkan skor min keseluruhan $(\min =3.58)$. Penglibatan aspek budaya Melayu ini melibatkan pelbagai komponen budaya yang meliputi tiga dimensi utama budaya, iaitu produk budaya, praktik budaya dan perspektif budaya. Ketiga-tiga dimensi budaya ini perlu diterapkan dalam PdP bahasa Melayu supaya pelajar memperoleh gambaran sebenar budaya Melayu.

\section{KESIMPULAN}

Kajian ini merupakan kajian tentang penerapan budaya Melayu dalam PdP Bahasa Melayu di TUFS, Jepun. Dapatan kajian menunjukkan bahawa majoriti pelajar menyokong aspek budaya Melayu dimasukkan dalam kurikulum Bahasa Melayu. Kajian juga mendapati penglibatan aspek budaya Melayu merangkumi tiga dimensi budaya seperti yang dikemukakan dalam kerangka budaya 3P. Hal ini jelas membuktikan bahawa aspek budaya merangkumi tiga dimensi utama, iaitu produk, praktik dan perspektif yang saling berkait rapat dan tidak boleh diabaikan dalam PdP bahasa Melayu. Ketigatiga dimensi ini merangkumi komponen budaya Melayu yang lain. Antara komponen penting yang perlu diterapkan dalam PdP bahasa Melayu adalah agama Islam yang menjadi teras kepada budaya Melayu, falsafah masyarakat Melayu di samping komponen-komponen budaya yang lain. Penerapan aspek budaya ini mampu memberikan penjelasan kepada pelajar dan dapat memacu pelajar ke arah penggunaan bahasa Melayu yang tepat sama ada secara lisan mahupun tulisan. Justeru, aspek budaya Melayu perlu diterapkan dalam PdP bahasa Melayu dan tidak boleh diabaikan untuk memastikan pelajar mempelajari dan menguasai bahasa Melayu sepenuhnya. 


\section{RUJUKAN}

Awang, S., Maros, M. \& Ibrahim, N. (2012). Malay values in intercultural communication. International Journal of Social Science and Humanity 2(3): 201-205. doi:10.7763/IJSSH.2012.V2.96

Brown, H. D. 2007. Principles of Language Learning and Teaching, hlm. 5th Edition. United States of America: Pearson Education, Inc.

Byrd, D. R., Hlas, A. C., Watzke, J. \& Valencia, M. F. M. (2011). An examination of culture knowledge : A study of 12 teachers ' and teacher educators ' beliefs and practices. Foreign Language Annals 44(1): 4-39.

Chi-Jung, T. \& Chuan-Ta, C. (2012). Teaching culture in Taiwan's EFL classroom. Procedia - Social and Behavioral Sciences 47: 1843-1846. doi:10.1016/j.sbspro.2012.06.910

Dahlan Abdul Ghani. (2015). Upin \& Ipin: Promoting Malaysian culture values through animation. Historia $y$ Comunicacion Social 20(1): 241-258. doi:10.5209/rev-HICS.2015.v20.n1.49558

Dahlia Zawawi. (2009). Cultural dimensions among Malaysian employees. International Journal of Economics and Management 2(2): 409-426.

Darmo, I. S. (2015). Millennials green culture: The opportunity and challenge (A case study of higher education student). The 3rd International Multidisciplinary Conference on Social Sciences (IMCoSS 2015), hlm. 2128. Bandar Lampung University.

Goddard, C. \& Wierzbicka, A. (1997). Discourse and culture. Dlm. Teun A. Van (pnyt.). Discourse as Social Interaction, hlm. 231-259. London: Sage Publications.

Gorjian, B. \& Aghvami, F. (2017). The comparative study of EFL teachers and learners 'perceptions on the importance of teaching culture. Journal of Applied Linguistics and Language Learning 3(3): 71-78. doi:10.5923/j.jall1.20170303.03

Idris Zakaria. (2012). Islam dan falsafahnya dalam kebudayaan. Jurnal Hadhari Special Edition 91-108.

Junaini Kasdan, Yusmaniza Mohd Yusoff, Nor Hashimah Jalaluddin \& Hasnah Mohamad. 2018. Pembangunan kit video pembelajaran bahasa Melayu penutur asing berteraskan budaya. PENDETA Journal of Malay Language, Education and Literature 9: 144-157.

Khumsikiew, J., Donsamak, S. \& Saeteaw, M. (2015). A model of small-group problem-based learning in pharmacy education: Teaching in the clinical environment. IAFOR Journal of Education 3(2): 95-108. doi:10.22492/ije.3.2.06

Kramsch, C. (1991). Culture in language learning: A view for the United Stated. Dlm. Bot (pnyt.), Ginsberg (pnyt.), \& Kramsch (pnyt.). Foreign Language Research in Cross-Cultural Perspective, hlm. 217-240. Amsterdam: John Benjamins Publishing Company.

Kuo, M.-M. \& Lai, C.-C. (2006). Linguistics across cultures: The Impact of culture on second language learning. Journal of Foreign Language Instruction 1-10. Retrieved from https://eric.ed.gov/?id=ED496079

Li, X. \& Umemoto, K. (2010). Toward an integrated approach to teaching Japanese language and culture : A knowledge perspective. Intercultural Communication Studies 285-299.

Liddicoat, A. J. \& Crozet, C. (1997). Teaching language teaching culture. Australian Review of Applied Linguistics 1-22. Retrieved from papers2://publication/uuid/219E1E70-45D9-4B93-8C98298B90A20A12

Liu, K. (2013). The culture study in foreign language education. International Review of Social Sciences and Humanitie 6(1): 196-204.

Mahmoud, M. M. A. (2015). Culture and English language teaching in the Arab world. Adult Learning 26(2): 66-72. doi:10.1177/1045159515573020

Mardian Shah Omar, Azman Rahmat \& Yusfarina Mohd Yussof. (2017). Menyulam budaya dalam pengajaran bahasa Melayu untuk penutur asing. Jurnal Linguistik 21(2): 81-92.

Mazlina Baharudin \& Siti Ajar Ikhsan. (2016). The interesting teaching and learning of Malay language to foreign speakers : Language through cultures. Dinamika Ilmu 16(1): 1-13. doi:10.21093/di.v16i1.295

Muho, A. \& Roseni, E. (2016). Integrating culture in teaching English as a second language. International Conference on Lingusitics, Literatutre and Culture, hlm. 52-63. doi:10.24252/eternal.v12.2015.a12

Mumu, E. L. (2017). An Exploration of Teachers'Beliefs on the Integration of Culture in Teaching English as a Foreign Language in Junior High Schools in Minahasa/Indonesia. Murdoch University, Western Australia.

Qu, Y. (2010). Culture understanding in foreign language teaching. English Language Teaching 3(4): 58-62.

Rajabi, S. \& Ketabi, S. (2012). Aspects of cultural elements in prominent English textbooks for EFL setting. Theory and Practice in Language Studies 2(4): 705-712. doi:10.4304/tpls.2.4.705-712

Razi, S. (2012). Developing the inventory of cultural components to assess perception in language learning. Novitas ROYAL Reasearch on Youth and Language 6(2): 169-186.

Roshidah Hassan. (2017). Gaya dan strategi pembelajaran bahasa Melayu dalam kalangan pelajar Perancis. GEMA Online ${ }^{\circledR}$ Journal of Language Studies 17(1): 125-146. doi:10.17576/gema-2017-1701-08 
Rostami, F. (2016). A comparative study of teachers' and learners' perceptions towards the role of culture in English Language Teaching. International Journal of Humanities and Cultural Studies (Special Issue (January)): 1061-1076.

Salim, S. K. (2017). Teaching language and teaching culture. 8th International visible Conference on Educational Studies \& Applied Linguistics 2017, hlm. 464-470. doi:10.23918/vesal2017.a34

Shirazi, E. (2017). Novice vs . Seasoned Iranian EFL teachers' beliefs and practices about intercultural communicative competence. Journal of Applied Linguistic and Language Research 4(6): 272-299.

Stockwell, E. (2018). Teaching culture in foreign language classes. Foreign Language Education Research 22: 11-23.

Wan Mohd Saophy Amizul Wan Mansor. (2006), November 22. Pengajian bahasa Melayu di Jepun. Berita Harian, p. 12. Dicapai daripada http://www.dbp.gov.my/klikdbp/klikdbp12nov6.pdf

Webb, S. (2018). Selecting television programs for language learning: Investigating television programs from the same genre. International Journal of English Studies 11(1): 117. doi:10.6018/ijes/2011/1/137131

Zaiton Zakarya \& Hawa Mahfuzah Rusidin. (2019). Isu dan cabaran pengajaran bahasa Melayu di luar negara: Pengalaman di Universiti China. Seminar Antarabangsa Susastera, Bahasa dan Budaya Nusantara, hlm. 377-391.

Zaitul Azma Zainon Hamzah \& Ahmad Fuad Mat Hassan. (2011). Bahasa dan pemikiran dalam peribahasa Melayu. GEMA Online Journal of Language Studies 11(3): 31-51.

Zulkifley Hamid. (2014). Faktor persekitaran sekolah dan etnik dalam perancangan dan pelaksanaan program pendidikan Bahasa Melayu di Malaysia. Geografia: Malaysian Journal of Society and Space 5(5): 85-95. Retrieved from http://journalarticle.ukm.my/7863/ 